\title{
KAJIAN MACAM PUPUK KANDANG TERHADAP PERTUMBUHAN DAN HASIL PADI MERAH ( Oryza sativa L. )
}

\author{
Yulyana Wulandari ${ }^{1 *}$, Siswadi $^{1}$, Kharis Triyono ${ }^{1}$ \\ ${ }^{1}$ Program Studi Agroteknologi Fakultas Pertanian Universitas Slamet Riyadi Surakarta \\ 1*yulyanawulandari@gmail.com
}

\begin{abstract}
Research on "Kinds of Manure Fertilizers Against Growth and Yield of Red Rice (Oryza Sativa L.)" was conducted from October 17th, 2018 to January 4th, 2019 in Brongsongan, Sidorejo Village, Bendosari District, Sukoharjo Regency. Place height is around 125 masl and the soil type is grumosol. This research aims: to determine the effect of giving manure to the growth and yield of red rice. This study uses a Complete Randomized Block Design (RAKL) with the Nested Design method. The treatment consisted of 4 types of treatment factors, each of which was repeated as many as 3 blocks / replications. The factors are: P0: Without giving manure, P1: Giving cow manure, P2: Giving goat manure, and P3: Giving chicken manure. Observations were made by taking 5 sample plants in each treatment. This data was analyzed using Variety Analysis, which was followed by the LSD Test at the level of 5\%. The results showed that (1) the treatment of manure did not significantly affect the growth of plant height and panicle length of rice plants, (2) the treatment of manure significantly affected the growth in the number of tillers and yields, namely the number of panicles, weight 100 seeds, dry weight and milled dry weight of rice plants. But from the results of these studies obtained the best growth and results found in P2, namely giving goat

manure.
\end{abstract}

Keywords : Manure, Red Rice, Growth and Yield

\begin{abstract}
ABSTRAK
Penelitian tentang “ Kajian Macam Pupuk Kandang Terhadap Pertumbuhan Dan Hasil Padi Merah ( Oryza Sativa L. ) " telah dilaksanakan mulai tanggal 17 Oktober 2018 sampai 04 Januari 2019 di Dusun Brongsongan Desa Sidorejo Kecamatan Bendosari Kabupaten Sukoharjo. Ketinggian tempat sekitar $125 \mathrm{mdpl}$ dan jenis tanahnya grumosol. Penelitian ini bertujuan : untuk mengetahui pengaruh pemberian macam pupuk kandang terhadap pertumbuhan dan hasil tanaman padi merah. Penelitian ini menggunakan Rancangan Acak Kelompok Lengkap (RAKL) menggunakan metode Nested Design. Perlakuan terdiri dari 4 macam faktor perlakuan, yang masing-masing diulang sebanyak 3 blok/ulangan. Adapun faktor tersebut adalah : P0 : Tanpa pemberian pupuk kandang, P1 : Pemberian pupuk kandang sapi, P2 : Pemberian pupuk kandang kambing, dan P3 : Pemberian pupuk kandang ayam. Pengamatan dilakukan dengan mengambil 5 tanaman sample pada setiap perlakuan. Data ini dianalisis menggunakan Analisis Ragam, yang dilanjutkan dengan Uji LSD pada taraf $5 \%$. Hasil penelitian menunjukkan (1) perlakuan macam pupuk kandang tidak berpengaruh nyata pada pertumbuhan tinggi tanaman dan panjang malai padi merah, (2) perlakuan pemberian macam pupuk kandang berpengaruh nyata tpada pertumbuhan jumlah anakan padi dan hasil yaitu pada jumlah malai, berat 100 biji, berat kering panen dan berat kering giling tanaman padi merah. Namun dari hasil penelitian tersebut didapat pertumbuhan dan hasil yang terbaik terdapat pada P2 yaitu pemberian pupuk kandang kambing.
\end{abstract}

Kata Kunci : Pupuk Kandang, Padi Merah, Pertumbuhan dan Hasil 


\section{PENDAHULUAN}

Padi merupakan komoditas makanan utama / pokok di Indonesia. Tingkat produksi maupun konsumsi di masyarakat, padi selalu menempati urutan pertama di antara komoditas tanaman pangan lainnya. Kebutuhan padi yang semakin meningkat tidak diikuti dengan produktivitas padi yang masih rendah sampai sekarang. Semakin meningkatnya kebutuhan beras di Indonesia mendorong pemerintah untuk memperluas lahan persawahan. Menurut Badan Pusat Statistik ( BPS 2018 ) produksi beras nasional pada tahun 2017 sebanyak 47,30 juta ton .

Upaya peningkatan produktivitas tanaman padi dan pendapatan petani perlu adanya peningkatan varietas - varietas padi yang unggul dan pemupukan yang berimbang. Banyak penelitian yang sudah dilakukan tentang varietas padi unggul, karena varietas padi unggul mempunyai beberapa kelebihan seperti umur panen yang pendek dan hasil produksi yang tinggi (Bambang et al.,2004). Dengan pemberian pupuk kandang dalam waktu yang relatif panjang dapat meningkatkan kelembaban tanah dan membangun kesuburan tanah ( Sutanto, 2002 ).

Didalam pupuk kandang terdapat sumber hara nitrogen, fosfor dan kalium yang dapat meningkatkan pertumbuhan dan perkembangan tanaman, serta mengandung mikroorganisme yang mampu menghancurkan sampah - sampah yang tedapat di dalam tanah dan berubah menjadi humus ( Soepardi, 1983 ). Secara biologi pupuk kandang akan memberikan ketesediaan unsur hara yang mampu diserap akar tanaman menjadikan tanaman tumbuh dan dapat mempengaruhi hasilnya ( Samekto dkk, 2006 ).

\section{METODE PENELITIAN}

Penelitian ini telah dilakukan pada bulan 17 Oktober 2018 - 04 Januari 2019, yang akan dilaksanakan di Dusun Brongsongan, Desa Sidorejo, Kecamatan Bendosari, Kabupaten Sukoharjo, dengan ketinggian tempat $125 \mathrm{mdpl}$ dan jenis tanahnya grumosol. Penelitian ini rancangan percobaannya yaitu Rancangan Acak Kelompok Lengkap (RAKL) menggunakan metode Nested Design dengan pemberian macam pupuk kandang $(\mathrm{P})$ terdapat 4 macam sebagai berikut : Tanpa Pemberian Pupuk Kandang (P0), Pupuk Kandang Sapi (P1), Pupuk Kandang Kambing (P2), Pupuk Kandang Ayam (P3). Setiap perlakuanya diulang sebanyak 3 ulangan, dalam setiap perlakuan terdapat 5 tanaman sample yang diamati.

Pengolahan tanah penyemaian dilakukan dengan menggunakan cangkul, kemudian baru diratakan. Melakukan seleksi benih yang kurang baik, dengan membuang benih yang terapung atau melayang. Melakukan perendaman benih dalam waktu 24 jam, kemudian ditiriskan lalu diperamkan. Lamanya pemeraman yaitu 48 jam, tujuannya agar benih berkecambah. Pada pengolahan tanah ini membuat petakan sebanyak 12 buah dengan ukuran $100 \mathrm{~cm}$ x $100 \mathrm{~cm}$, yang terdiri dari 3 blok / ulangan dengan arah tegak lurus. Kemudian di buat dengan jarak antar blok/ulangan $50 \mathrm{~cm}$, sedangkan jarak pada anak petak $25 \mathrm{~cm}$.

Pemberian perlakuan pupuk kandang dilakukan pada awal pengolahan tanah pada setiap petaknya dengan dosis pupuk kandang sapi sebanyak 7,5 ton/ha setara $750 \mathrm{gr} / \mathrm{petak}$, pupuk kandang kambing sebanyak 10 ton/ ha setara $1.000 \mathrm{gr} /$ petak, dan pupuk kandang ayam sebanyak 2 ton/ha setara $200 \mathrm{gr} /$ petak . Pindah tanam umur 21 hari, menggunakan jarak tanamnya yaitu $20 \mathrm{~cm} \times 20 \mathrm{~cm}$. Penyiangan dilakukan dua kali yaitu penyiangan awal dilakukan pada waktu tanaman padi sudah umur kira - kira 3 minggu dan yang selanjutnya 6 minggu setelah tanam. Pengairan dilakukan dengan cara mengalirkan air melalui saluran irigasi yang dibagikan ke areal persawahan.

Pemupukan dilakukan dengan dosis sesuai rekomendasi yaitu urea dosis 250 $\mathrm{kg} / \mathrm{ha}$, pupuk phospor dosis $100 \mathrm{~kg} / \mathrm{ha}$, pupuk $\mathrm{KCl}$ dosis $75 \mathrm{~kg} / \mathrm{ha}$. Pemberian pupuk phosphor diberikan satu hari sebelum tanam. Pemanenan dilakukan apabila biji padi telah menunjukkan ciri - ciri masak secara fisik yaitu 90\% - 95\% malai telah berwarna menguning, hitam dan merah tua. Benih padi memiliki umur panen rata - rata $90-110$ hst.

Variabel pengamatan penelitian ini adalah tinggi tanaman, jumlah anakan, panjang malai, jumlah malai, berat 100 biji, berat kering panen, dan berat kering giling. Data yang didapat dianalisis selanjutnya yaitu 
Uji LSD dalam taraf 5\% untuk mengetahui perlakuan pemberian pupuk yang berpengaruh dan yang tidak berpengaruh nyata.

\section{HASIL DAN PEMBAHASAN}

Hasil penelitian perlakuan macam pupuk kandang pada table 1 dapat dilihat bahwa tidak adanya pengaruh nyata pada tinggi tanaman.

Tabel 1. Rata - rata tinggi tanaman padi merah $(\mathrm{cm})$

\begin{tabular}{lcc}
\hline \multicolumn{1}{c}{ Perlakuan } & $\begin{array}{c}\text { Rata-rata Tinggi } \\
\text { Tanaman }(\mathrm{cm})\end{array}$ & $\begin{array}{c}\text { Hasil Uji LSD pada } \\
\text { taraf 5\% }\end{array}$ \\
\hline P0 = Tanpa Pupuk & 94.3 & $\mathrm{a}$ \\
P1 = Pupuk Kandang Sapi & 97.2 & $\mathrm{a}$ \\
P2 = Pupuk Kandang Kambing & 98.4 & $\mathrm{a}$ \\
P3 = Pupuk Kandang Ayam & 94.9 & $\mathrm{a}$ \\
\hline
\end{tabular}

Keterangan : Rata-rata tinggi tanaman diikuti huruf yang sama berarti tidak berbeda nyata pada taraf 5\% uji LSD

Menunjukan bahwa macam pupuk kandang tidak berpengaruh nyata pada tinggi tanaman namun cenderung meningkatkan tinggi tanaman terbaik pada (P2) yaitu pemberian pupuk kandang kambing sedangkan yang terendah $(\mathrm{P} 0)$ yaitu tanpa pemberian pupuk kandang. Hal ini juga tidak terlihat berbeda nyata pada pemberian pupuk kandang ayam (P3) maupun pupuk kandang sapi (P1).

Secara kuantitatif terdapat perbedaan kenaikan tinggi tanaman padi merah pada setiap perlakuan. Pemberian pupuk, baik jenis atau dosisnya akan memengaruhi pertumbuhan dan hasil tanaman padi ( Putra, 2012). Namun demikian, menurut Rahayu \& Harjoso (2011), pengaruh terhadap pertumbuhan tanaman bukan hanya karena factor pemberian pupuk tetapi faktor varietas juga sangat berpengaruh. Sedangkan Hoque et al. (2003) dan Warda (2011) menyatakan bahwa tinggi tanaman sangat dipengaruhi varietas dan galur yang memiliki adaptasi yang lebih baik terhadap lingkungan . Hasil penelitian pemberian macam pupuk kandang pada tabel 2 menunjukkan bahwa adanya pengaruh nyata pada jumlah anakan.

Tabel 2. Rata - rata jumlah anakan tanaman padi merah

\begin{tabular}{lcc}
\multicolumn{1}{c}{ Perlakuan } & $\begin{array}{c}\text { Rata-rata Jumlah } \\
\text { Anakan ( batang })\end{array}$ & $\begin{array}{c}\text { Hasil Uji LSD pada } \\
\text { taraf 5\% }\end{array}$ \\
\hline $\mathrm{P}_{0}=$ Tanpa Pupuk & 18.5 & $\mathrm{~b}$ \\
$\mathrm{P}_{1}$ = Pupuk Kandang Sapi & 16.9 & $\mathrm{a}$ \\
$\mathrm{P}_{2}$ = Pupuk Kandang Kambing & 19.2 & $\mathrm{c}$ \\
$\mathrm{P}_{3}=$ Pupuk Kandang Ayam & 15.3 & $\mathrm{a}$ \\
\hline
\end{tabular}

Keterangan : Rata-rata jumlah anakan diikuti huruf yang sama berarti tidak berbeda nyata pada taraf $5 \%$ uji LSD

Menunjukan bahwa tanpa pemberian pupuk kandang (P0) akan meningkatkan jumlah anakan dibandingkan dengan pemberian pupuk kandang sapi (P1) maupun pupuk kandang ayam (P3). Namun pemberian pupuk kandang kambing (P2) lebih meningkatkan jumlah anakan secara nyata dibandingkan tanpa pemberian pupuk kandang (P0). Unsur hara $\mathrm{P}$ sangat dibutuhkan tanaman padi, yang terpenting pada masa pertumbuhan, untuk mendorong pembentukan akar serta menambah jumlah anakan.
Peran penting unsur hara $\mathrm{P}$ bagi tanaman adalah memacu pertumbuhan dan membentuk akar, pada suhu iklim rendah mampu membantu berbunga dan kematangan buah, pemulihan pembentukan anakan yang lebih banyak, dan mampu beradaptasi waktu mengalami cekaman (De Datta, 1981). Marschner (1995) juga menyatakan bahwa unsur hara yang tersedia cukup dalam tanah terutama $\mathrm{N}, \mathrm{P}$ dan $\mathrm{K}$ dapat merangsang pembentukan anakan. Hasil penelitian perlakuan macam pupuk kandang pada tabel 3 dapat dilihat bahwa tidak adanya pengaruh nyata terhadap panjang malai. 
Tabel 3. Rata - rata panjang malai tanaman padi merah $(\mathrm{cm})$

\begin{tabular}{lll}
\hline Perlakuan & $\begin{array}{l}\text { Rata-rata Panjang } \\
\text { Malai }(\mathrm{cm})\end{array}$ & $\begin{array}{l}\text { Hasil Uji LSD pada } \\
\text { taraf 5\% }\end{array}$ \\
\hline P0 = Tanpa Pupuk & 23.9 & a \\
P1 = Pupuk Kandang Sapi & 24.8 & a \\
P2 = Pupuk Kandang Kambing & 25.2 & a \\
P3 = Pupuk Kandang Ayam & 24.3 & a \\
\hline Ke
\end{tabular}

Keterangan : Rata-rata panjang malai diikuti huruf yang sama berarti tidak berbeda nyata pada taraf $5 \%$ uji LSD

Menunjukan bahwa macam pupuk kandang kambing (P2) cenderung meningkatkan panjang malai walaupun tidak adanya pengaruh nyata dibanding tanpa pemberian pupuk kandang (P0), pemberian pupuk kandang sapi $(\mathrm{P} 1)$ dan pemberian pupuk kandang ayam (P3). Malai terbentuk ketika memasuki fase generatif, pada fase ini padi memerlukan ketersediaan air yang cukup dan kebutuhan unsur $\mathrm{N}$ yang tersedia bagi tanaman karena pada fase ini juga sel sel tanaman sangat aktif membelah dan

Tabel 4. Rata - rata jumlah malai padi

\begin{tabular}{lcc}
\multicolumn{1}{c}{ Perlakuan } & $\begin{array}{c}\text { Rata-rata Jumlah } \\
\text { Malai (helai) }\end{array}$ & $\begin{array}{c}\text { Hasil Uji LSD pada } \\
\text { taraf 5\% }\end{array}$ \\
\hline P0 = Tanpa Pupuk & 11.7 & $\mathrm{c}$ \\
P1 = Pupuk Kandang Sapi & 11.67 & $\mathrm{~b}$ \\
P2 = Pupuk Kandang Kambing & 12.0 & $\mathrm{~d}$ \\
P3 = Pupuk Kandang Ayam & 9.1 & $\mathrm{a}$ \\
\hline
\end{tabular}

Keterangan : Rata-rata jumlah malai diikuti huruf yang sama berarti tidak berbeda nyata pada taraf 5\% uji LSD

Menunjukan pemberian macam pupuk kandang sapi (P1) meningkatkan jumlah malai jika dibandingkan dengan pemberian pupuk kandang ayam (P3), namun meningkatkan jumlah malai yang lebih banyak yaitu pada tanpa pemberian pupuk kandang (P0) dan pemberian pupuk kandang kambing (P2). De Datta (1981) menyatakan bahwa ketidakseimbangan antara $\mathrm{N}$ dan $\mathrm{P}$ serta ketersedian air bagi tanaman akan proses pembelahan akan semakin baik jika suplai $\mathrm{N}$ tersedia bagi tanaman. Terbentuknya malai betina dipengaruhi oleh suplai nitrogen stadia pemisah sel - sel primordial buku leher malai ( Mega et al., 1970). Panjang malai akan semakin meningkat jika pemberian pupuk kandang kambing pada dosis yang tepat bagi tanaman Hasil penelitian pemberian macam pupuk kandang pada tabel 4 menunjukkan bahwa adanya pengaruh nyata pada jumlah malai. mempengaruhi jumlah malai yang terbentuk. Unsur P ditemukan relatif dalam jumlah lebih banyak dalam buah dan biji tanaman (Rosmarkam \& Yuwono, 2002). Selain hara $\mathrm{P}$, banyaknya malai yang terbentuk juga dipengaruhi oleh ketersediaan air pada saat pembentukan malai Hasil penelitian pemberian macam pupuk kandang pada tabel 4 menunjukkan bahwa adanya pengaruh nyata pada berat 100 biji.

Tabel 5. Rata - rata berat 100 biji per sample pada tanaman padi merah (gr)

\begin{tabular}{lccc}
\hline \multicolumn{1}{c}{ Perlakuan } & $\begin{array}{c}\text { Berat 100 Biji } \\
(\mathrm{gr})\end{array}$ & $\begin{array}{c}\text { Hasil Uji LSD pada } \\
\text { taraf 5\% }\end{array}$ \\
\hline P0 = Tanpa Pupuk & 2.59 & $\mathrm{a}$ & \\
P1 = Pupuk Kandang Sapi & 2.60 & $\mathrm{a}$ & \\
P2 = Pupuk Kandang Kambing & 3.00 & $\mathrm{~b}$ & \\
P3 = Pupuk Kandang Ayam & 2.59 & $\mathrm{a}$ & \\
\hline
\end{tabular}

Keterangan : Rata-rata berat 100 biji diikuti huruf yang sama berarti tidak berbeda nyata pada taraf 5\% uji LSD

Menunjukan pupuk kandang kambing (P2) meningkatkan berat 100 biji 
(P1), dan pupuk kandang ayam (P3). Unsur kalium $(\mathrm{K})$ dibutuhkan tanaman padi dalam pembentukan dan pengisisan bulir. Banyaknya bahan kering yang terdapat dalam biji akan mempengaruhi tinggi atau rendahnya pada berat biji. Proses fotosintesis hasilnya dapat digunakan sebagai pengisian untuk biji sehingga diperoleh bahan kering didalam biji Masdar (2007). Sumardi (2007) menyatakan bobot kering 100 biji ditentukan oleh genetiknya, tapi faktor lingkungan juga berpengaruh terhadap faktor pembentukan berat bijinya. Faktor lingkungan dan daya serap hara tanaman juga berpengaruh penting pada bobot gabah. Hasil penelitian pemberian macam pupuk kandang pada tabel 6 menunjukkan bahwa adanya pengaruh nyata pada berat kering panen.

Tabel 6. Rata - rata berat kering panen pada tanaman padi merah (gr)

\begin{tabular}{lcc}
\hline \multicolumn{1}{c}{ Perlakuan } & $\begin{array}{c}\text { Berat Kering } \\
\text { Panen }(\mathrm{gr})\end{array}$ & $\begin{array}{c}\text { Hasil Uji LSD pada } \\
\text { taraf 5\% }\end{array}$ \\
\hline P0 = Tanpa Pupuk & 15.68 & $\mathrm{a}$ \\
P1 = Pupuk Kandang Sapi & 16.47 & $\mathrm{a}$ \\
P2 = Pupuk Kandang Kambing & 17.16 & $\mathrm{~b}$ \\
P3 = Pupuk Kandang Ayam & 14.86 & $\mathrm{a}$ \\
\hline
\end{tabular}

Keterangan : Rata-rata berat kering panen diikuti huruf sama berarti tidak nyata pada taraf 5\% uji LSD

Menunjukan pupuk kandang kambing (P2) meningkatkan berat kering panen secara nyata dibandingkan pemberian pupuk ayam (P3), pemberian pupuk kandang sapi (P1), dan tanpa pemberian pupuk kandang (P0). Kalium dalam pertanaman padi dibutuhkan dalam jumlah banyak, bahkan melebihi kebutuhan N. Sekitar 75\% dari kebutuhan $\mathrm{K}$ pada tanaman padi yang diambil sebelum fase bunting dan $25 \%$ sisanya diserap sebelum mulai pembentukan biji. Unsur kalium $(\mathrm{K})$ dibutuhkan tanaman padi dalam pembentukan dan pengisisan bulir. Menurut Soepardi (1983), kalium sangat penting untuk pembentukan protein dan selulosa. Selain itu, respon tanaman pada pemupukan akan meningkat dan penggunaan pupuk $\mathrm{N}$ dan $\mathrm{P}$ akan lebih efisiensi. Kalium dalam jumlah yang cukup akan menjamin ketegakan tanaman dan merangsang pembentukan akar. Lebih lanjut Supartha et al. (2012) menyatakan bahwa untuk meningkatkan pertumbuhan tanaman dan hasil gabah per rumpun dengan adanya unsur hara mikro dan makro yang terdapat pada pupuk kandang. Hasil penelitian pemberian macam pupuk kandang pada tabel 7 menunjukkan bahwa adanya pengaruh nyata pada berat kering giling.

Tabel 7. Rata - rata berat kering giling padi (gr)

\begin{tabular}{lcc}
\hline \multicolumn{1}{c}{ Perlakuan } & $\begin{array}{c}\text { Rata-rata Berat } \\
\text { Kering Giling }(\mathrm{gr})\end{array}$ & $\begin{array}{c}\text { Hasil Uji LSD } \\
\text { pada taraf 5\% }\end{array}$ \\
\hline P0 = Tanpa Pupuk & 12.86 & $\mathrm{a}$ \\
P1 = Pupuk Kandang Sapi & 13.03 & a \\
P2 = Pupuk Kandang Kambing & 15.45 & $\mathrm{~b}$ \\
P3 = Pupuk Kandang Ayam & 13.01 & a \\
\hline
\end{tabular}

Keterangan : Rata-rata berat kering giling diikuti huruf sama berarti tidak berbeda nyata pada taraf 5\% uji LSD

Menunjukan pupuk kandang kambing (P2) meningkatkan berat kering giling secara nyata dibandingkan tanpa pemberian pupuk kandang (P0), pemberian pupuk ayam (P3), dan pemberian pupuk kandang sapi (P1). Pada waktu tanaman menjelang fase generatif, sebagian banyak unsur P diangkut ke biji serta bagian tanaman yang memiliki fase generatif. Bagian bagian tanaman yang memliki fase generatif membutuhkan unsur $\mathrm{P}$ lebih banyak jika dibanding pada bagian tanaman yang tidak memilki fase generatif (Winarso, 2005). Pengeringan gabah padi menjadi bagian terpenting dalam berat kering giling yang pelaksanaannya harus diperhatikan. Apabila dalam proses pengeringan gabah mengalami kehilangan air yang banyak maka akan berpengaruh meningkatnya atau menurunnya pada berat kering giling padi. 


\section{KESIMPULAN}

Berdasarkan hasil penelitian dan pembahasan, maka dapat diperoleh kesimpulan : Pemberian macam pupuk kandang tidak adanya pengaruh nyata pada pertumbuhan tinggi tanaman dan hasil panjang malai tanaman padi merah. Pemberian pupuk kandang kambing adanya pengaruh nyata pada pertumbuhan jumlah anakan dan hasil pada jumlah malai, berat 100 biji, berat kering panen dan berat kering giling. Hasil terbaik pemberian macam pupuk kandang terhadap pertumbuhan dan hasil padi merah yaitu pupuk kandang kambing.

\section{DAFTAR PUSTAKA}

Badan Pusat Statistik. 2018. Statistik Pertanian Tanaman Pangan. Jakarta : Kantor Statistik.

Bambang. S. Zulkifli, Z, Diah, W. 2004. Kebijakan Perbesaran dan Inovasi Teknologi Padi. Bogor : Puslitbang Tanaman Pangan.

De Datta, S.K. 1981. Principle and Practices of Rice Production. A Wiley. New York : Interscience Publication

Hoque, M.M., Moynul, M., Hossain, M.M., Khan, M.R.H., Khalequzzaman, K.M. \& Karim, S.M.R. (2003). Effect of varieties of rice and weeding on weed growth and yield of transplant Aman rice. Asian Journal of Plant Sciences, 2(13), 993-998.

Marschner, H. (1995). Mineral Nutrition in Higher Plants. New York : Academic Press

Masdar. 2007. Interaksi jarak tanam dan jumlah bibit per titik tanaman pada system intensifikasi padi terhadap pertumbuhan vegetatif tanaman. Jurnal Akta Agrosia. Edisi Khusus (1): 92-98.

Putra, S. (2012). Pengaruh pupuk NPK tunggal, majemuk, dan pupuk daun terhadap peningkatan produksi padi gogo varietas Situ Patenggang. Agrotrop: Journal on Agriculture Science, 2(1), 55-61.
Rahayu, A. Y. \& Harjoso, T. (2011). Aplikasi abu sekam pada padi gogo (Oryza sativa L.) terhadap kan-dungan silikat dan prolin daun serta amilosa dan protein biji. Fakultas Pertanian. Universitas Jenderal Soedirman. Journal of Biota, 16(1), 48-55.

Rosmarkam, A. \& Yuwono, N.W. 2002. Ilmu Kesuburan Tanah. Yogyakarta : Kanisius

Samekto dan Riyo, 2006. Pupuk Kandang. Yogyakarta : Citra Aji Parama. Sumardi. (2007). Peningkatan Produksi Sawah Melalui Perbaikan Lingkungan Tumbuh Dalam Meningkatkan Hubungan Sourcesink Tanaman pada Metode SRI (The System Rice Intensification). Program Pasca Sarjana. Universitas Andalas, Padang.

Supartha, I.N.Y., Wijana, G. \& Andyana, G.M. (2012). Aplikasi jenis pupuk organik pada tanaman padi sistem pertanian organik. E Jurnal Agroekoteknologi Tropika, 1(2), 98106.

Sutanto. R. 2002. Pertanian Organik Menuju Pertanian Alternatif dan Berkelanjutan. Yogyakarta : Kanisius.

Warda. (2011). Keragaman Beberapa Varietas Unggul Padi di Kabupaten Bantaeng Sulawesi Selatan. Sulawesi Selatan. Balai Pengkajian Teknologi PertanianSulawesi Selatan. Prosiding Seminar Nasional Serealia.

Winarso, S.2005. Kesuburan Tanah:Dasar Kesehatan dan Kualitas Tanah. Jogjakarta : Gava media. 269 hal. 